\title{
ФОРМУВАННЯ МИСТЕЦЬКОЇ КУЛЬТУРИ МАЙБУТНЬОГО ВЧИТЕЛЯ ПОЧАТКОВИХ КЛАСІВ ЯК УМОВИ ЙОГО ТВОРЧОГО РОЗВИТКУ В КОНТЕКСТІ ПРОФЕСІЙНОЇ КОМПЕТЕНТНОСТІ
}

Лисевич О. В. Формування мистецької культури майбутнього вчителя початкових класів як важливої умови його творчого розвитку в контексті професійної компетентності.

У статті розглянуто проблему формування мистецької культури майбутнього вчителя початкових класів, підходи та шляхи іiі формування. Указано на необхідність створення умов, які сприяли б проявам творчої активності, створенні творчого мікроклімату, проблемно-пошукової атмосфери формування позитивних мотивів творчої діяльності. Акцентовано на створені умов для прояву творчості в педагогічній діяльності.

Ключові слова: мистецька культура, творча особистість, творчий потенціал, творчий процес, творче середовище, професіоналізм майбутніх учителів початкових класів, професійна компетентність.

Лисевич А. В. Формирование культуры будущего учителя начальных классов посредством искусства как необходимое условие его творческого развития в контексте профессиональной компетентности.

В статье рассматривается проблема формирования культуры будущего учителя начальных классов посредством искусства как условие его творческого развития в контексте профессиональной компетентности. Указано, что необходимо создать условия, которые способствовали б проявлениям творческой активности, творческой атмосферы, необходимой для формирования позитивной мотивации, творческой деятельности. Акцентировано на создании условий для проявления творчества в педагогической деятельности.

Ключевые слова: искусство, культура, творческая личность, творческий потенциал, творческий процесс, творческая среда, профессионализм будущих учителей начальных классов, профессиональная компетентность.

Lysevitch O. V. The formation of the art culture of the future primary school teachers by means of art as the necessary condition of their creative development in the context of professional competence.

The article examines the problem of the formation of the art culture of the future primary school teachers, by means of art as the necessary condition of their creative development in the context of professional competence. The author states that it is necessary to create the circumstances which would stimulate the creative activity, and the creative atmosphere which is of great need for the formation of positive motivation and creative activity. The author also insists that the presence of creative personalities, creative process, and creative environment are the important factors for the realization of the pedagogical creativity in the process of teaching.

Key words: art culture, creative personality, creative potential, creative process, creative environment, the professionalism of the future primary school teacher, professional competence.

Загальна мистецька освіта з їі можливостями впливу на людину повинна розглядатися не лише як процес набуття художніх знань і вмінь, а як універсальний засіб особистісного розвитку та показник професійної компетентності майбутнього вчителя початкових класів. У 
контексті нового розуміння функцій і принципів мистецької освіти, необхідно наголосити на органічній єдності національного (державного), регіонального (краєзнавчого) компонентів освіти 3 пріоритетністю поліхудожності, що відображається у змісті освіти між видами мистецтв та варіативності, спрямованої на художньо-естетичний розвиток особистості.

У зв'язку 3 цим мистецька культура майбутнього вчителя початкових класів розглядається як необхідна умова професійної самореалізації та показник професійної компетентності майбутнього вчителя.

У сучасних умовах постає суперечність між декларованою гуманізацією, переходом від технократичної до культурної концепцій освіти, яку розглядають як самовизначення особистості в культурі, становлення індивіда як людини культури та небажанням, невмінням, незацікавленістю майбутніх вчителів сприйняти, осягнути i трансформувати надбання світової та вітчизняної культури.

Сучасна мистецька освіта обумовлена низкою етичних проблем, деякі 3 них мають передісторію, але є й такі, що з'явилися в останні десятиріччя як результат змін у соціальнопсихологічній атмосфері світу. У більшості своїй вони пов'язані з психологією сучасної людини, 3 утилітарним ставленням людини до мистецтва. Найсерйознішою є проблема мотивації, відсутність розв'язання якої призводить до недооцінювання предметів художньоестетичного циклу на всіх рівнях: як у педагогічному середовищі, так і з боку студентів, школярів та їх батьків.

Сучасні тенденції розвитку мистецької освіти, зокрема освітньої галузі «Мистецтво», обумовлюють необхідність удосконалення професійних умінь вчителя початкових класів, що викладає дисципліни художньо-естетичного циклу. Значення професіоналізму учителя початкових класів у процесі викладання мистецьких дисциплін висвітлюється у працях Л. Бабенко, Е. Бєлкіної, Л. Бичкової, О. Гайдамаки, Є. Ковальова, С. Коновець, Л. Хомич, Г. Петрової, О. Рудницької, Л. Любарської, Л. Масол, О. Шевнюк, В. Холопової, І. Руденко, О. Ростовського.

Отже, метою статті є спроба виокремити основні підходи та шляхи формування мистецької культури в майбутніх учителів початкових класів як необхідної умови їх творчого розвитку та професійної компетентності.

Є кілька підходів до трансляції учням початкових шкіл мистецьких знань. У Франції, Ірландії, Іспанії, Нідерландах до мистецького блоку включають дисципліни пластичного мистецтва (малювання, живопис, ручну працю), музику та драму. У Німеччині формують у дітей також і навички танцю.

В інших країнах, таких, наприклад, як Швеція, викладають музику та ручну працю, а у Сполученому королівстві учні у мистецькому блоці вивчають мистецтво, дизайн, музику і танець (як складник фізкультури). Об’єднує усі вищезгадані країни практико-орієнтований, інтегрований підхід до реалізації викладання мистецької складової [11, с. 27].

Отже, велике значення на сучасному етапі має культурно-особистісний розвиток майбутнього вчителя, який повинен сприяти формуванню в учнів початкових класів комплексу ключових, міжпредметних естетичних $\mathrm{i}$ предметних мистецьких компетентностей. За цей напрям відповідають як традиційні предмети стандарту початкової освіти, так і інтегровані, зокрема «Мистецтво» як предмет, що сприяє формуванню основ цілісної картини світу, осмислення різноманітних зв'язків у системі «мистецтво - культура компетентність».

В Українському педагогічному словнику визначено культуру як «сукупність практичних, матеріальних і духовних надбань суспільства, які відображають історично 
досягнутий рівень розвитку суспільства й людини та втілюються у результатах продуктивної діяльності. У вужчому розумінні культура - це сфера духовного життя суспільства, що охоплює, насамперед, систему виховання, освіти, духовної творчості, а також установи й організації, що забезпечують їхнє функціонування (школи, ВНЗ, музеї тощо). Водночас під культурою розуміють рівень освіченості, вихованості людей, а також рівень оволодіння якоюсь галуззю знань або діяльністю» [3, с. 182].

Отже, ми розглядаємо культуру як своєрідну систему адаптації, яка дозволяє швидко пристосовуватись до оточуючого середовища.

Погоджуємось 3 думкою В. Синенка, який зазначає, що професійна компетентність майбутніх учителів - це мета та результат процесу підготовки, якісна характеристика майбутніх учителів, а професіоналізм є деякою перспективою, яка певною мірою доступна в силу індивідуальних можливостей та об'єктивних факторів [10, с. 45].

Отже, інтерпретація поведінки людини пов'язана передовсім 3 тим культурним середовищем, представником якого вона є. Культура відображає результати людського розвитку i має особистісно-творчу природу. Результатом педагогічної творчості $\epsilon$ педагогічна культура. Підкреслюючи творчу природу педагогічної культури, В. Сластьонін зазначає: «Культура - це завжди творчість, вона завжди розрахована на адресат, на діалог, а «засвоєння « iii $\epsilon$ процес особистісного відкриття, створення світу культури у собі, співпереживання і співтворчості, де кожний новий елемент культури не перекреслює попередній пласт культури» [9].

Сучасна методика пропонує як варіант інтегрування домінантних змістових ліній музичної та образотворчої, які органічно поєднуються в єдиний тематичний цикл на основі естетико-світоглядної орієнтації. Спільними для всіх видів мистецтва є відображення в художніх образах закономірностей людського буття, що зумовлює єдину тематичну структуру програми «Мистецтво», логіку об’єднання навчального матеріалу в цілісні тематичні блоки. Розумінню специфіки художньо-образної мови кожного з видів мистецтва сприяє інтеграція елементів змісту на основі єдності універсальних художньо-естетичних понять («ритм», «контраст», «симетрія», «форма», «композиція», «динаміка» тощо). Особливості спільних тем, споріднених художньо-мовних аспектів змісту зумовлюють процес застосування [6, с. 271].

Погляд на розвиток мистецького сприймання як «фундаменту мистецької культури», досить не однозначний. Багато зарубіжних психологів і педагогів вважають, що головне завдання - створити умови для розвитку сприймання, вітчизняна практика виходить 3 положення, що процес розвитку сприймання необхідно організовувати [4].

Процес сприймання творів може відбуватися свідомо та несвідомо, може завершуватися після осмислення твору, а може продовжуватися деякий час, перериватися та бути неперервним [7].

Діяльність слухача, глядача завжди направлена на засвоєння змісту художнього твору. Зміст твору - це сформоване у свідомості уявлення про сам твір, про оточуючий світ $\mathrm{i}$ слухача, глядача у ньому, про автора, виконавця.

На першому етапі формуються уявлення, обумовлені тільки сприйманням певного твору. Це уявлення про твір - його будову, багатобарвність, а також переживання, викликані сприйманням твору; уявлення естетичні, світоглядні й асоціативні - результат порівняння почутого, пережитого й усвідомленого з вже відомим через життєвий досвід. Особливість таких уявлень полягає в тому, що вони відображають особистісний світ слухача - його естетичні уявлення та переживання, його естетичні оцінки, світоглядні уявлення, асоціації. 
Повнота та глибина вищезазначених уявлень буде різною через соціально-психологічну різницю між людьми, різний обсяг знань, необхідних для усвідомлення вихідних уявлень.

Другий етап процесу сприйняття - інтерпретація, осмислення вихідних змістовних уявлень і переживань, які можуть бути обумовлені лише смаками, потребами, позицією автора, тощо.

Методику викладання цікавлять такі питання: як слухач, глядач у деталях і загалом сприймають твір, як твір розвивається у вигляді специфічного процесу, які психологічні умови забезпечують художньо-естетичне переживання, розуміння, оцінку, адекватність сприйняття задуму твору.

Саме у сприйманні, особливо в його розвиненій формі проявляється творчість глядача, слухача. Сприймання - поняття історичне, соціальне, вікове. Воно обумовлене системою детермінант: твором, загальним історичним, життєвим, жанрово-комунікативним контекстом, зовнішніми та внутрішніми умовами сприймання, віком і статтю. На сприймання впливають стиль твору та жанр.

Сприймання розглядається як активна творча діяльність, оскільки під час слухання, споглядання відбувається постійний слуховий, зоровий контроль, відбувається процес упізнавання. Необхідно зауважити, що мистецьке сприймання відрізняється яскравою емоційністю й образністю. Воно торкається різних аспектів емоційної сфери. Під час мистецького сприймання відбуваються такі логічні операції як осмислення, порівняння, 3 якими, в свою чергу, пов'язані осмисленість та асоціативність [7].

Формування повноцінного мистецького сприймання свідчить про складний взаємопов'язаний процес: по-перше, про інтелектуальний ріст людини, по-друге, про удосконалення ії основних мистецьких здібностей.

Якщо проаналізувати педагогічний процес у контексті формування творчої особистості майбутнього вчителя початкових класів, то можна виокремити в ньому два напрямки: перший пов'язаний з процесом підготовки педагога до творчості, а другий творчість під час безпосередньої взаємодії студентів 3 творами мистецтва. Спілкування 3 творами мистецтва, як компонент педагогічної творчості, творчість у спілкуванні викладача і студента - як необхідна умова продуктивної педагогічної діяльності.

Багато дослідників звертає увагу на те, що у викладанні педагог спирається на здатність студентів до запам'ятовування, а не на евристичне мислення, імпровізацію, тощо. Науковці вказують на необхідність у створенні умов, які сприяють проявам творчої активності, створенні творчого мікроклімату, проблемно-пошукової атмосфери, необхідної для формування позитивних мотивів креативної діяльності.

Мистецька освіта апелює до комплексу методів загальної та спеціальної педагогіки, направлених на розвиток здібностей, мистецького сприймання, при цьому провідну роль відіграє мотивація та зацікавленість. Найбільш дієвим у методиці є метод емоційного впливу, пов'язаний 3 образним та яскравим мовленням педагога, його здатністю приваблювати словом; він направлений на емоційну сферу, образне мислення. Сформований інтерес викликає ефект подиву, розвиває пам'ять, фантазію, мислення.

Ситуація успіху концентрує волю, дієвість, актуалізує попередній досвід. Створена на заняттях ігрова ситуація сприяє активності, фантазуванню, переключенню уваги, тощо.

Група методів і прийомів має інтелектуальне значення: проблемно-пошукова ситуація концентрує увагу, волю, образне та логічне мислення, уяву; дискусія сприяє розвитку логічного мислення, мовлення, пам'яті.

Метод стимулювання діяльності створює емоційно насичену атмосферу, сприяє 
прояву індивідуальності, виховує художні потреби, творчі навички та прийоми. Важливою властивістю цього методу є стимулювання репродуктивного та творчого потенціалу.

У багатьох дослідженнях стверджується, що творчий потенціал притаманний кожній особистості, але у різній кількості та якості, проблема полягає тільки у з'ясуванні механізмів його розкриття.

Особливості творчості в навчанні та вихованні, механізми творчої діяльності розглядалися у працях В. Давидова, І. Зимньої, Н. Кузьміна, О. Матюшкіна, Я. Пономарьова.

Творчість як основа та механізм розвитку психіки досліджувалася у працях Н. Кіпіані, I. Семенова та ін.; творчість та закономірності мислення розглядалися Н. Алексєєвим, С. Бернштейном, В. Біблером, О. Тихомировим, Е. Юдіним.

У контексті педагогічної діяльності проблема творчості розглядалася М. Поташником, який наголошує на iї практичному застосуванні: нестандартний підхід до розв'язання проблем; розроблення нових методів, засобів, прийомів і форм у оригінальному поєднанні; ефективне застосування досвіду; удосконалення, раціоналізація, модернізація відомого відповідно до нових задач; імпровізація на основі як інтуїції, так і перевірених знань; уміння бачити всі варіанти проблеми; уміння трансформувати методичні рекомендації, теоретичні положення у конкретні педагогічні дії.

М. Поташник розрізняе «педагогічну майстерність» i «педагогічну творчість», наголошуючи на тому, що майстерність пов'язана з досвідом, а творчість - ні [8].

Ефективність формування творчої особистості майбутніх учителів початкових класів у контексті професійної компетентності зумовлена виявленням умов та подоланням суперечностей між вимогами, що висуваються до особистості та діяльності майбутнього вчителя початкових класів та наявним рівнем культури загалом та мистецької культури зокрема. Стан досліджуваної проблеми формування мистецької культури майбутніх учителів початкових класів вимагає подальших наукових пошуків: методика діагностики рівня сформованості мистецької культури майбутнього вчителя початкових класів, показники та критерії іiі сформованості, розроблення моделі та технології іï формування в контексті професійної компетентності.

\section{Література}

1. Асафьев Б. В. Избранные статьи о музыкальном просвещении и образовании / Б. В. Астафьев. - [2-е изд.]. - Ленинград : Музыка, 1973. - 144 с. 2. Выготский Л. С. Психология искусства / Лев Семенович Выготский. - Санкт-Петербург : Питер, 2000. - 416 с. 3. Гончаренко С. У. Український педагогічний словник / Семен Устинович Гончаренко. Київ : Либідь, 1997. - 376 с. 4. Коновець С. В. Образотворче мистецтво в початковій школі / С. В. Коновець. - Київ, 2000. - 79 с. 5. Морозов А. В. Креативная педагогика и психология: [учеб. пособ.] / А. В. Морозов, Д. В. Чернилевский. - Москва : Академический Проект, 2004. - [2-е изд., испр. и доп.]. - 560 с. 6. Навчальні програми для загальноосвітніх навч. закл. із навчанням українською мовою. 1-4 класи. - Київ : Видавничий дім «Освіта», 2012. 392 с. 7. Овсянкина Г. П. Музыкальная психология: [учеб. для факультетов музыки педагогических университетов, консерваторий и гуманитарных вузов] / Галина Петровна Овсянкина. - Санкт-Петербург : Питер, 2007. - 240 с. 8. Поташник М. М. Требования к современному уроку: [учеб. пособ.]/ Марк Максимович Поташник. - Москва: Центр педагогического образования, 2011. - 272 с. 9. Сластенин В. А. Введение в педагогическую аксиологию: [учеб. пособ. для студ. высш. пед. учеб. заведений]/ В. А. Сластенин, Г. И. Чижакова. - Москва : Академия, 2003. - 192 с. 10. Синенко В. Я. Профессионализм учителя / В. Я. Синенко // Педагогика. - 1999. - №5. - С. 45-52. 11. The Arts, Creativity and 
Cultural Education An International Perspective. December 2000 // INCA (International Review of Curriculum and Assessment Frameworks Internet Archive). London: INCA, QCA, nfer, 2000. -58 p.

УДК 378.14

Юлія Мельничук

\section{ФОРМУВАННЯ ГОТОВНОСТІ МАЙБУТНІХ УЧИТЕЛІВ ПОЧАТКОВИХ КЛАСІВ ДО ОРГАНІЗАЦІЇ СПІЛКУВАННЯ УЧНІВ}

Мельничук Ю. Ю. Формування готовності майбутніх учителів початкових класів до організації спілкування учнів.

У статті на основі вивчення теоретичних праць, присвячених проблемі професійнопедагогічної підготовки майбутніх учителів початкових класів, розкрито різні підходи до ії трактування, визначено змістові компоненти та 3'ясовано сутність готовності студентів до організації спілкування молодших школярів у процесі навчання.

Ключові слова: підготовка майбутніх учителів початкових класів, організація спілкування, готовність до педагогічної діяльності, вольові якості, комунікативні уміння.

Мельничук Ю. Ю. Формирование готовности будущих учителей начальных классов к организации общения учащихся.

В статье на основе изучения теоретических работ, посвященных проблеме профессионально-педагогической подготовки будущих учителей начальных классов, раскрыты различные подходы к ее трактовке, определены содержательные компоненты и описана сущность готовности студентов к организации общения младших школьников в процессе обучения.

Ключевые слова: подготовка будущих учителей начальных классов, организация общения, готовность к педагогической деятельности, волевые качества, коммуникативные умения.

Melnychuk $\mathrm{Yu} . \mathrm{Yu}$. The formation of rediness of future primary school reachers for the organization of pupils' communication.

In the article based on the study of theoretical works on the problem of professional and pedagogical training of future primary school teachers, various approaches to its understanding are shown, substantial components are defined and the essence of readiness of students for the organization of junior schoolchildren communication in the process of training is described.

Key words: future primary school reachers training, organization of communication, readiness for pedagogical activity, volitional powers, communication skills.

Проблема підготовки вчителя початкових класів до організації спілкування молодших школярів є частиною загальної проблеми підготовки вчителя у системі вищої педагогічної освіти.

Аналіз психолого-педагогічної літератури показав, що удосконалення підготовки вчителів до навчально-виховної роботи залишається актуальною проблемою сучасної педагогічної освіти (О. Абдуліна, С. Архангельський, Є. Белозерцев, В. Сластьонін, Л. Спірін, Г. Троцко та ін.).

У педагогіці та психології вищої школи інтенсивно розробляються проблеми 